\title{
АДМИНИСТРАТИВЫНЕ ПРАВОНАРУШЕНИЯ В СФЕРЕ ЗАЩИТЫ ПРАВ НА ОБЪЕКТЫ ИНТЕЛЛЕКТУАЛЬНОЙ СОБСТВЕННОСТИ, ОТНЕСЕННЫЕ К КОМПЕТЕНЦИИ ТАМОЖЕННЫХ ОРГАНОВ
}

\begin{abstract}
Аннотация: Статья посвящена проблемным вопросам в системе правоотношений в области Развитие теопроизводства по делам об административных правонарушениях в сфере защиты прав на объекты интеллектуальной собственности, отнесенных к компетенции таможенных органов, в условиях функционирования Таможенного союза, особенностям возбуждения дел об административных правонарушениях по статье 14.10 Кодекса Российской Федерации об административных правонарушениях в случаях незаконного использования чужого товарного знака, проблемам доказывания вины лица, перемещающего контрафактные товары, вопросам совершенствования взаимодействия заинтересованных контролирующих органов не только российских, но и контролирующих органов государств - членов Таможенного союза В основу научного исследования положены сравнительный и научный методы исследования, направленные на совершенствование производства по делам об административных правонарушениях в срере интеллектуальной собственности На основе анализа общественных отношений, складывающихся в рамках производства по делам об АП в сфере защиты прав на объекты интеллектуальной собственности, отнесенных к компетенции таможенных органов, в условиях функционирования Таможенного союза, автором сформулированы предложения по совершенствованию законодательства в области производства по делам об АП и взаимодействию контролирующих органов в указанной срере. 1.Для решения задач, указанных в Стратегии, в целях пресечения правонарушений в срере интеллектуальной собственности, необходимо унифицировать законодательства об АП государств - членов Таможенного союза. 2. Необходимо совершенствовать межведомственное и международное взаимодействие, на наднациональном уровне (уровне Таможенного Союза), например, единая информационная база документов различных контролирующих органов, взаимодействующих с таможенными службами Таможенного союза.

Ключевые слова: административное правонарушение, защита исключительных прав;, объекты интеллектуальной собственности, Таможенный союз, контрафактная продукция, правообладатель, товарный знак, однородные товары, эксперт, перемещение.
\end{abstract}

3 ащита исключительных прав на объекты интеллектуальной собственности на протяжении последних лет стала проблемой мирового масштаба. Методы изготовителей и продавцов контрафакта с каждым годом становятся все изощренней, борьба с контрафактом - жестче и эффективнее.

Как свидетельствует статистика, количество возбуждаемых таможенными органами дел об административныхправонарушениях (далее - АП), связанных с нарушением прав на интеллектуальную собственность, на протяжении последнего времени остается стабильно высокой (в год более чем 1 тыс. дел).

По сравнению с первым полугодием прошлого года увеличилось число дел об АП, возбужденных по части 1 статьи 7.12 и статье 14.10 Кодекса Российской Федерации об административных правонарушениях (далее - КоАП РФ) ${ }^{1}$ (с 507 за первое

\footnotetext{
1 Письмо ФТС России от 01.04.2014 № 18-12/14619 «О направлении информационно-аналитического обзора право-
}

полугодие 2012 года до 521 за первое полугодие 2013 года).

Большинство дел данной категории возбуждено по фактам незаконного использования товарного знака, знака обслуживания, наименования места происхождения товара или сходных с ними обозначений для однородных товаров. В течение первого полугодия 2013 года по статье 14.10 КоАП РФ возбуждено 510 дел об АП (в аналогичном периоде 2012 года - 498 дел об АП). Значительно меньше дел об АП возбуждено по части 1 статьи 7.12 КоАП РФ в связи с нарушением авторских и смежных прав (11 дел). Например, Южным таможенным управлением возбуждено наибольшее (112 дел) количество дел указанной категории в связи с ввозом на территорию Российской Федерации контрафактной продукции.

охранительной деятельности таможенных органов Российской Федерации (данные за 12 месяцев 2013 года)». 
В других регионах деятельности: в Дальневосточной (96 дел), Северо-Западной (85 дел), Сибирской (76 дел), Центральной (54 дела), Северо-

Кавказской 30 дел) и Приволжской (20 дел) оперативных таможен. Из таможен, непосредственно подчиненных ФТС России, больше всего дел возбуждено Шереметьевской таможней (31 дело).

Предметами АП в основном являлись одежда, обувь, игрушки, косметика, продукты питания, алкогольная продукция, автозапчасти и мобильные телефоны.

Субъектами АП являлись как юридические лица, так и физические лица, которые под видом товаров для личного пользования ввозят на таможенную территорию Российской Федерации коммерческие партии контрафактных товаров. Данная категория дел об АП является наиболее сложной, поскольку решения по результатам их рассмотрения принимаются только судами, которыми дается оценка правомерности возбуждения таможенными органами дел об АП и совершенных ими процессуальных действий, достаточности собранных доказательств.

Кроме того, в отличие от других составов правонарушений, расследуемых таможенными органами, в таких делах всегда присутствует потерпевшая сторона - правообладатель на объекты интеллектуальной собственности, которому правонарушителем причинен немалый экономический ущерб, нанесен урон деловой репутации и имиджу.

В таких условиях цена процессуальной ошибки должностного лица таможенного органа, осуществляющего административное расследование, может оказаться слишком высокой.

Для обеспечения полного, всестороннего и объективного расследования дел об АП Управлением таможенных расследований и дознания ФТС России (далее - УТРД ФТС России) разработаны и направлены в таможенные органы Методические рекомендации по квалификации и расследованию АП в сфере интеллектуальной собственности. В данном документе пошагово изложены действия должностных лиц таможенных органов по возбуждению и расследованию дел об административных правонарушениях по части 1 статьи 7.12 и статьи 14.10 КоАП Р $\Phi^{2}$.

Кроме того, УТРД ФТС России регулярно осуществляется анализ проблемных вопросов, свя-

\footnotetext{
2 Письмо ФТС России от 16.07.2008 № 18-12/28610 «О направлении методических рекомендаций».
}

занных с производством по делам об АП указанной категории, например, в связи с проведением в 2014 году Олимпийских игр в г. Сочи, прогнозируя повышенный интерес покупателей к продукции с олимпийской символикой, а, следовательно, и увеличению рынка соответствующей конрафактной продукции, изучается складывающаяся судебная практика. По результатам такой работы в таможенные органы направлен обзор ${ }^{3}$, в котором разъяснены указанные вопросы.

Так, Президиумом Высшего Арбитражного Суда 3 февраля 2009 г. № 10458/08 вынесено решение об отмене решений судов первой и апелляционной инстанций и об отказе в удовлетворении заявления Центральной акцизной таможни о привлечении лица к административной ответственности по делу об АП, возбужденному в связи с ввозом без разрешения правообладателя на таможенную территорию Российской Федерации автомобиля, произведенного правообладателем одноименных товарных знаков ${ }^{4}$.

В данном решении указано, что в соответствии со статьей 14.10 КоАП РФ на юридических лиц может быть наложен административный штраф с обязательной конфискацией только таких предметов, которые содержат незаконное воспроизведение товарного знака, знака обслуживания, наименования места происхождения товара.

Следовательно, не могут быть привлечены к административной ответственности, предусмотренной статьей 14.10 КоАП РФ лица, ввезшие на территорию Российской Федерации без разрешения правообладателя товары с размещенными на них одноименными товарными знаками, не содержащие признаков незаконного воспроизведения товарных знаков.

С этой целью до возбуждения дел об АП в рамках таможенного контроля необходимо проводить проверочные мероприятия, в ходе которых устанавливать, нанесен ли зарегистрированный в установленном порядке товарный знак на товар правообладателем либо товар содержит незаконное воспроизведение товарного знака.

Диспозиция статьи 14.10 КоАП РФ устанавливает ответственность за незаконное использова-

\footnotetext{
3 Письмо ФТС России от 30.10.2009 № 18-12/51934 «Обзор правоприменительной практики по делам об административных правонарушениях в сфере интеллектуальной собственности».

4 Постановление Президиума Высшего Арбитражного Суда от 03.02.2009 № 10458/08 // «Вестник Высшего Арбитражного Суда Российской Федерации». 2009 № 5.
} 
ние товарного знака, знака обслуживания, наименования места происхождения товара или сходных с ними обозначений только для однородных товаров.

В этой связи в предмет доказывания входит не только установление обстоятельств ввоза на территорию Таможенного союза товара, маркированного определенным товарным знаком без разрешения правообладателя, но и установление однородности ввозимого товара тому товару, в отношении которого товарный знак зарегистрирован. Именно совокупность указанных обстоятельств позволяет сделать вывод о наличии в действиях лица, привлекаемого к административной ответственности, состава правонарушения, предусмотренного ст. 14.10 КоАП РФ.

Следует отметить, что одним из проблемных вопросов является вопрос правомерности возбуждения дела об АП при ввозе контрафактных товаров на таможенную территорию Таможенного союза в отношении перевозчика (железнодорожного перевозчика в том числе). В данном случае у железнодорожного перевозчика отсутствуют правовые и реальные возможности для проверки значительных объемов перемещаемых грузов на предмет их контрафактности, так как в соответствии с международными договорами и национальным законодательством Российской Федерации при принятии товаров к перевозке он не вправе требовать документы, подтверждающие соблюдение исключительного права правообладателя.

Оказывая услуги по перевозке, перевозчик не может пользоваться и распоряжаться товаром, то есть использовать его, извлекать выгоду («пользу») ${ }^{5}$. Указанные обстоятельства свидетельствуют об отсутствии в действиях перевозчика состава АП.

При вынесении определений о назначении патентоведческих экспертиз перед экспертом ставится вопрос, является ли товар контрафактным. Однако в компетенцию эксперта не входит признание товара контрафактным, поскольку данный вопрос решается судом. Поэтому в определении о назначении экспертизы перед экспертом следует ставить вопрос об отличительных признаках товара, наличие которых свидетельствует о том, что товары произведены не правообладателем товарного знака.

5 Ожегов С.И. Словарь русского языка: 70000 слов / под общ. ред. проф. Л.И. Скворцова. 24-е изд., исправленное. М. «ОНИКС 21 век» «Мир» «Образование» 2004. С. 547.
Имеют место случаи, когда в качестве экспертного учреждения назначается Федеральная служба по интеллектуальной собственности, патентам и товарным знакам. Однако в соответствии с Положением о Федеральной службе по интеллектуальной собственности, утвержденным постановлением Правительства Российской Федерации 21.03.2012 № 218 «0 федеральной службе по интеллектуальной собственности», в функции службы не входит осуществление экспертной деятельности, в связи с чем, давать поручение руководителю данной службы на проведение экспертизы и разъяснение эксперту его прав, обязанностей и ответственности неправомерно 6 .

Вместе с тем отдельные специалисты Роспатента, получившие соответствующие сертификаты, могут выступать в качестве экспертов. При назначении экспертизы необходимо выяснять наличие у эксперта соответствующего сертификата.

При производстве по делам об АП в области интеллектуальной собственности одним из проблемных вопросов является правомерность возбуждения одного дела об АП в случае, когда в ходе таможенного контроля обнаружены товары, содержащие незаконное воспроизведение товарных знаков, принадлежащих разным правообладателям, ввезенные по одному контракту, в адрес одного и того же получателя, являющегося декларантом, заявленные в одной таможенной декларации и в одной товарной позиции.

Согласно части 1 статьи 28.2 КоАП РФ по каждому факту совершения АП составляется протокол об АП.Из содержания диспозиции статьи 14.10 КоАП РФ следует, что фактом совершения АП признается каждое незаконное использование чужого товарного знака, знака обслуживания, наименования места происхождения товара или сходных с ними обозначений для однородных товаров.

Учитывая изложенное, в приведенной ситуации незаконное использование каждого товарного знака, знака обслуживания, наименования места происхождения товара или сходных с ними обозначений для однородных товаров является самостоятельным АП и по каждому такому факту необходимо возбуждать дело об АП.

При выявлении в ходе расследования дел об АП, возбужденных в связи с нарушениями таможенных

6 Постановление Правительства Российской Федерации от 21.03.2012 № 218 «О федеральной службе по интеллектуальной собственности» [Электронный ресурс]. Доступ из «КонсультантПлюс» (дата обращения: 24.02.2014). 
правил, правонарушений в области интеллектуальной собственности у таможенных органов возникают проблемы, связанные с изъятием либо арестом предмета правонарушения, когда товар, содержащий незаконное воспроизведение товарного знака, одновременно является предметом АП, совершенного путем недекларирования либо недостоверного декларирования товара, поскольку КоАП РФ не предусматривает отмену меры обеспечения административного производства, принятой по одному делу об АП в целях ее применения по другому делу.

Санкция статьи 14.10 КоАП РФ в отличие от большинства статей главы 16 КоАП РФ предусматривает обязательную конфискацию товаров, являющихся предметом правонарушения, в связи с этим товар подлежит изъятию либо аресту в рамках дела об АП, возбужденного по данной статье.

Поэтому в ходе административного расследования по делам о нарушениях таможенных правил, после проведения всех необходимых для разрешения дела действий с товаром, являющимся предметом АП, следует к материалам дела об АП, возбужденного по статье главы 16 КоАП РФ, приобщать копия протокола о применении меры обеспечения по делу, возбужденному по статье 14.10 КоАП РФ.

Отмечались случаи, когда правообладатели после установления таможенным органом признаков «контрафактности» товаров не обращались в таможенный орган с заявлением о привлечении недобросовестного участника ВЭД к административной ответственности, что на практике приводило к невозбуждению таможней дел об АП. Кроме того, в некоторых случаях от правообладателя поступала информация об отсутствии претензий к лицу, осуществившему ввоз поддельных товаров, в связи с заключением лицензионного договора или достижения иного соглашения, что приводило к прекращению производства по делам об АП.

Вместе с тем после опубликования постановления Президиума ВАС России от 04.09.2012 № $3127 / 12$, согласно которому наличие договоренности между правообладателем и участником ВЭД после факта ввоза контрафактных товаров, не исключает в действиях лица, в отношении которого возбуждено дело об АП, наличие состава АП, предусмотренного статьей 14.10 КоАП РФ, вопрос о правомерности возбуждения дела об АП в указанном случае был исключен ${ }^{7}$.

Постановление Президиума Высшего Арбитражного Суда от 04.09.2012 № 3127/12. [Электронный ресурс]. Доступ из «КонсультантПлюс» (дата обращения: 24.02.2014).
При выявлении контрафактных товаров, которые вывозятся с таможенной территории Таможенного союза, ряд таможенных органов направляют материалы в органы внутренних дел для возбуждения дел об АП, мотивируя свою позицию тем, что возбуждение дел по фактам производства, продажи, хранения или перевозки контрафактных товаров не относится к компетенции таможенных органов, поскольку данные действия не связаны с перемещением таких товаров через таможенную границу Таможенного союза.

Однако следует учитывать, что согласно Таможенному кодексу Таможенного союза ${ }^{8}$ (далее - ТК TC) одной из функций таможенных органов является обеспечение в пределах своей компетенции защиты прав интеллектуальной собственности, а также пресечение незаконного оборота через таможенную границу объектов интеллектуальной собственности.

В Федеральном законе от 27.11.2010 г. № 311Ф3 «0 таможенном регулировании в Российской Федерации» ${ }^{9}$ также установлены порядок и основания применения таможенными органами мер в отношении товаров, содержащих объекты интеллектуальной собственности.

В силу положений ТК ТС меры принимаются при перемещении товаров через таможенную границу или совершении иных действий с товарами, находящимися под таможенным контролем. Российские товары считаются находящимися под таможенным контролем при их вывозе с таможенной территории Таможенного союза с момента принятия таможенной декларации или совершения действий, непосредственно направленных на вывоз товаров с таможенной территории Таможенного союза и до пересечения таможенной границы Таможенного союза.

В случае перемещения товаров с незаконным использованием чужого товарного знака, знака обслуживания, наименования места происхождения товара или сходных с ним обозначений для однородных товаров через таможенную границу Таможенного союза либо в случае нахождения их

\footnotetext{
8 Таможенный кодекс Таможенного союза (приложение к Договору о Таможенном кодексе Таможенного союза, принятому Решением Межгосударственного совета ЕврАзЭС на уровне глав государств от 27.11.2009 № 17) (в ред. от 16.04.2010) // Собрание законодательства РФ.2010. № 50. Ст. 6615.

9 Федеральный закон от 27.11.2010 № 311-Ф3 «О таможенном регулировании в Российской Федерации» // Российская газета. 2010.29 ноября.
} 
под таможенным контролем должностные лица таможенных органов обладают полномочиями по составлению протоколов об АП, предусмотренных статьей 14.10 КоАП РФ.

Объективная сторона АП в данных случаях будет выражаться в производстве, продаже, хранении или перевозке контрафактных товаров.

Согласно Стратегии развития таможенной службы Российской Федерации до 2020 года (далее - Стратегия) одной из основных задач в области совершенствования таможенного регулирования является: предотвращение и пресечение международной торговли контрафактной продукцией путем расширения полномочий таможенных органов по пресечению правонарушений в сфере интеллектуальной собственности ${ }^{10}$.

Нельзя не согласиться с автором С.А. Агамагомедовой в том, что необходимо унифицировать и законодательства государств - членов Таможенного союза путем внесения соответствующих изменений в Таможенный кодекс Таможенного союза, поскольку принцип «ех officio» в качестве меры по пресечению правонарушений в сфере интеллектуальной собственности должен быть обязателен для всех государств - членов Таможенного союза (республики Казахстан и Беларусь данное полномочие таможенных органов в своем национальном законодательстве не закрепили ${ }^{11}$.

Следует поддержать предложенный начальником Управления организации предоставления государственных услуг Федеральной службы по интеллектуальной собственности (Роспатент) O.В. Добрыниным комплекс мероприятий, направленных на совершенствование работы по предотвращению правонарушений в указанной сфере: оказание необходимого содействия в сотрудничестве, изучение опыта зарубежных специалистов, ознакомление с практикой международного сотрудничества, организация учебных программ, проведение совместных семинаров ${ }^{12}$.

10 Распоряжение Правительства РФ от 28.12.2012 № 2575$\mathrm{p}$ «О стратегии развития таможенной службы Российской Федерации до 2020 года» // Собрание законодательства РФ. 2013. № 2. Ст. 109.

11 Агамагомедова С. А. Модель административно - правового механизма защиты прав на объекты интеллектуальной собственности таможенными органами на территории Евразийского экономического пространства // Вестник Российской таможенной академии. 2013. № 4. С. 46-47.

12 Добрынин О.В. Взаимодействие Роспатента и ФТС России по вопросам обеспечения защиты прав интеллектуальной собственности//Доклад начальника начальника Управ-
Анализ действующего административноправового механизма защиты прав на объекты интеллектуальной собственности, осуществляемого таможенными органами государств - членов Таможенного союза, показал, что должностные лица таможенных органов только Российской Федерации уполномочены возбуждать дела об АП, связанные с нарушением авторских и смежных прав, изобретательских и патентных прав (часть 1 статьи 7.12 КоАП РФ), а также незаконным использованием товарного знака (статья 14.10 КоАП РФ), и осуществлять по ним административное расследование.

Белоруссия и Казахстан в настоящее время данные полномочия должностных лиц таможенных органов в своем законодательстве об административных правонарушениях не закрепили: статьи 636 Кодекса об административных правонарушениях Республики Казахстан ${ }^{13}$ и 3.30 Процессуально-исполнительного кодекса Республики Беларусь ${ }^{14}$ не содержат составов правонарушений, предусматривающих административную ответственность за нарушения в сфере интеллектуальной собственности, по которым должностные лица таможенных органов имеют право составлять протоколы об АП. Кроме того, требуют совершенствование взаимодействия заинтересованных контролирующих органов не только российских, но и контролирующих органов государств - членов Таможенного союза.

На основе анализа общественных отношений, складывающихся в рамках производства по делам об АП в сфере защиты прав на объекты интеллектуальной собственности, отнесенных к компетенции таможенных органов, в условиях функционирования Таможенного союза, автором сформулированы предложения по совершенствованию законодательства в области производства по делам об АП и

ления организации предоставления государственных услуг Роспатента, кан. юрид. наук на Всероссийском семинар-совещании по вопросам защиты прав интеллектуальной собственности таможенными органами Российской Федерации 2-6 сентября 2013 г. Иркутск.

13 Кодекс об административных правонарушениях Республики Казахстан: Закон Республики Казахстан от 30.01.2001 № 156-II [Электронный ресурс]. URL: http://www.zakon. kz/static/administrativnyykodex.html / (дата обращения: 24.02.2014).

14 Процессуально-исполнительный кодекс Республики Беларусь: Закон Республики Беларусь от 20.12.2006 № 194-3 [Электронный ресурс]. URL: http://tamby.info/kodeks/pikoap. htm / (дата обращения: 24.02.2014). 
взаимодействию контролирующих органов в указанной сфере.

1. Для решения задач, указанных в Стратегии, в целях пресечения правонарушений в сфере интеллектуальной собственности, необходимо унифицировать законодательства об АП государств членов Таможенного союза.

2. Необходимо совершенствовать межведомственное и международное взаимодействие, на наднациональном уровне (уровне Таможенного Союза), например, единая информационная база документов различных контролирующих органов, взаимодействующих с таможенными службами Таможенного союза.

Таким образом, предложенные унификация законодательства государств - членов Таможенного союза и совершенствование межведомственного и межгосударственного взаимодействия позволит существенно повысить эффективность производства по делам об АП в сфере защиты прав интеллектуальной собственности, отнесенных к компетенции таможенных органов в условиях функционирования Таможенного союза.

\section{Библиография:}

1. Кодекс Российской Федерации об административных правонарушениях. (в ред. от 15.02.2014 № 6-Ф3) // Собрание законодательства РФ.2002, № 1 (ч. 1). Ст. 1.

2. Письмо ФТС России от 16.07.2008 № 18-12/28610 «О направлении методических рекомендаций».

3. Письмо ФТС России от 30.10.2009 № 18-12/51934 «Обзор правоприменительной практики по делам об административных правонарушениях в сфере интеллектуальной собственности».

4. Постановление Президиума Высшего Арбитражного Суда от 03.02.2009 № 10458/08 // «Вестник Высшего Арбитражного Суда Российской Федерации». 2009 №

5. Ожегов С.И. Словарь русского языка: 70000 слов / под общ. ред. проф. Л.И. Скворцова. 24-е изд.,исправленное. М. «ОНИКС 21 век» «Мир» «Образование» 2004. С. 547.

6. Постановление Правительства Российской Федерации от 21.03 .2012 № 218 «0 федеральной службе по интеллектуальной собственности» [Электронный ресурс]. Доступ из «КонсультантПлюс» (дата обращения: 24.02.2014).

7. Постановление Президиума Высшего Арбитражного Суда от 04.09.2012 № 3127/12. [Электронный ресурс]. Доступ из «КонсультантПлюс» (дата обращения: 24.02.2014).

8. Таможенный кодекс Таможенного союза (приложение к Договору о Таможенном кодексе Таможенного союза, принятому Решением Межгосударственного совета ЕврАзЭС на уровне глав государств от 27.11.2009 № 17) (в ред. от 16.04.2010) // Собрание законодательства РФ.2010. № 50. Ст. 6615.

9. Федеральный закон от 27.11.2010 № 311-Ф3 «0 таможенном регулировании в Российской Федерации» // Российская газета. 2010.29 ноября.

10. Распоряжение Правительства РФ от 28.12.2012 № 2575-р «0 стратегии развития таможенной службы Российской Федерации до 2020 года» // Собрание законодательства РФ. 2013. № 2. Ст. 109.

11. Агамагомедова С. А. Модель административно-правового механизма защиты прав на объекты интеллектуальной собственности таможенными органами на территории Евразийского экономического пространства // Вестник Российской Таможенной академии. 2013. № 4. С. 46-47.

12. Добрынин О.В. Взаимодействие Роспатента и ФТС России по вопросам обеспечения защиты прав интеллектуальной собственности//Доклад начальника начальника Управления организации предоставления государственных услуг Роспатента, кан. юрид. наук на Всероссийском семинар-совещании по вопросам защиты прав интеллектуальной собственности таможенными органами Российской Федерации 2-6 сентября 2013 г. Иркутск.

13. Кодекс об административных правонарушениях Республики Казахстан: Закон Республики Казахстан от 30.01.2001 № 156-II [Электронный ресурс].URL: http://www.zakon.kz/static/administrativnyykodex.html / (дата обращения: 24.02.2014).

14. Процессуально-исполнительный кодекс Республики Беларусь: Закон Республики Беларусь от 20.12.2006 № 1943 [Электронный ресурс]. URL: http://tamby.info/kodeks/pikoap.htm / дата обращения: 24.02.2014).

15. Агамагомедова C.А. Порядок действий таможенных органов РФ по защите прав на объекты интеллектуальной собственности и его оптимизация в современных условиях // Административное и муниципальное право. 2014. - 6. - C. 559 - 568. DOI: 10.7256/1999-2807.2014.6.10860.

16. С.А. Агамагомедова Административная ответственность за незаконное использование товарных знаков (по материалам деятельности таможенных органов). // Административное и муниципальное право. - 2011. - 2. - С. 70 - 73.

17. Агамагомедова С.А. Правовые основы и особенности административной защиты олимпийской и паралимпийской символики таможенными органами Российской Федерации // Административное и муниципальное право. 2012. - 9. - С. $81-91$. 


\section{References (transliterated):}

1. Kodeks Rossiiskoi Federatsii ob administrativnykh pravonarusheniyakh. (v red. ot 15.02.2014 № 6-FZ) // Sobranie zakonodatel'stva RF.2002, № 1 (ch. 1). St. 1.

2. Pis'mo FTS Rossii ot 16.07.2008 № 18-12/28610 «0 napravlenii metodicheskikh rekomendatsii».

3. Pis'mo FTS Rossii ot 30.10.2009 № 18-12/51934 «Obzor pravoprimenitel'noi praktiki po delam ob administrativnykh pravonarusheniyakh v sfere intellektual'noi sobstvennosti».

4. Postanovlenie Prezidiuma Vysshego Arbitrazhnogo Suda ot 03.02.2009 № 10458/08 // «Vestnik Vysshego Arbitrazhnogo Suda Rossiiskoi Federatsii». 2009 №

5. Ozhegov S.I. Slovar' russkogo yazyka: 70000 slov / pod obshch. red. prof. L.I. Skvortsova. 24-e izd.,ispravlennoe. M. «ONIKS 21 vek» «Mir» «Obrazovanie» 2004. S. 547.

6. Postanovlenie Pravitel'stva Rossiiskoi Federatsii ot 21.03 .2012 № 218 «O federal'noi sluzhbe po intellektual'noi sobstvennosti» [Elektronnyi resurs]. Dostup iz «Konsul'tantPlyus» (data obrashcheniya: 24.02.2014).

7. Postanovlenie Prezidiuma Vysshego Arbitrazhnogo Suda ot 04.09.2012 № 3127/12. [Elektronnyi resurs]. Dostup iz «Konsul'tantPlyus» (data obrashcheniya: 24.02.2014).

8. Tamozhennyi kodeks Tamozhennogo soyuza (prilozhenie k Dogovoru o Tamozhennom kodekse Tamozhennogo soyuza, prinyatomu Resheniem Mezhgosudarstvennogo soveta EvrAzES na urovne glav gosudarstv ot 27.11.2009 № 17) (v red. ot 16.04.2010) // Cobranie zakonodatel'stva RF.2010. № 50. St. 6615.

9. Federal'nyi zakon ot 27.11.2010 № 311-FZ «0 tamozhennom regulirovanii v Rossiiskoi Federatsii» // Rossiiskaya gazeta. 2010.29 noyabrya.

10. Rasporyazhenie Pravitel'stva RF ot 28.12.2012 № 2575-r «0 strategii razvitiya tamozhennoi sluzhby Rossiiskoi Federatsii do 2020 goda» // Sobranie zakonodatel'stva RF. 2013. № 2. St. 109.

11. Agamagomedova S. A. Model' administrativno-pravovogo mekhanizma zashchity prav na ob"ekty intellektual'noi sobstvennosti tamozhennymi organami na territorii Evraziiskogo ekonomicheskogo prostranstva // Vestnik Rossiiskoi Tamozhennoi akademii. 2013. № 4. S. 46-47.

12. Dobrynin O.V. Vzaimodeistvie Rospatenta i FTS Rossii po voprosam obespecheniya zashchity prav intellektual'noi sobstvennosti//Doklad nachal'nika nachal'nika Upravleniya organizatsii predostavleniya gosudarstvennykh uslug Rospatenta, kan. yurid. nauk na Vserossiiskom seminar-soveshchanii po voprosam zashchity prav intellektual'noi sobstvennosti tamozhennymi organami Rossiiskoi Federatsii 2-6 sentyabrya 2013 g. Irkutsk.

13. Kodeks ob administrativnykh pravonarusheniyakh Respubliki Kazakhstan: Zakon Respubliki Kazakhstan ot 30.01 .2001 № 156-II [Elektronnyi resurs].URL: http://www.zakon.kz/static/administrativnyykodex.html / (data obrashcheniya: 24.02.2014).

14. Protsessual'no-ispolnitel'nyi kodeks Respubliki Belarus': Zakon Respubliki Belarus' ot 20.12.2006 № 194-Z [Elektronnyi resurs]. URL: http://tamby.info/kodeks/pikoap.htm / data obrashcheniya: 24.02.2014).

15. Agamagomedova S.A. Poryadok deistvii tamozhennykh organov RF po zashchite prav na ob"ekty intellektual'noi sobstvennosti i ego optimizatsiya v sovremennykh usloviyakh // Administrativnoe i munitsipal'noe pravo. - 2014. - 6. C. 559 - 568. DOI: 10.7256/1999-2807.2014.6.10860.

16. S.A. Agamagomedova Administrativnaya otvetstvennost' za nezakonnoe ispol'zovanie tovarnykh znakov (po materialam deyatel'nosti tamozhennykh organov). // Administrativnoe i munitsipal'noe pravo. - 2011. - 2. - C. 70 - 73.

17. Agamagomedova S.A. Pravovye osnovy i osobennosti administrativnoi zashchity olimpiiskoi i paralimpiiskoi simvoliki tamozhennymi organami Rossiiskoi Federatsii // Administrativnoe i munitsipal'noe pravo. - 2012. - 9. - C. 81 - 91. 